\title{
Modification of corn stalk for high-performance adsorption of Coomassie Brilliant blue dye in simulated polluted water: kinetic study
}

\author{
Taha N.A. ${ }^{*}{ }^{\text {, Zattot A. }}{ }^{2}$ and Mohamed E. ${ }^{2}$ \\ ${ }^{1}$ Modeling and Simulation Research Department, Advanced Technology and New Materials Research Institute, City for Scientific \\ Research and Technology Applications (SRTACITY), New Borg El-Arab City 21934, Alexandria, Egypt \\ ${ }^{2}$ Chemical Engineering Department, Faculty of Engineering, Alexandria University \\ Received: 04/05/2021, Accepted: 25/05/2021, Available online: 31/05/2021 \\ *to whom all correspondence should be addressed: e-mail: nahlataha_1982@yahoo.com \\ https://doi.org/10.30955/gnj.003701
}

\section{Graphical abstract}
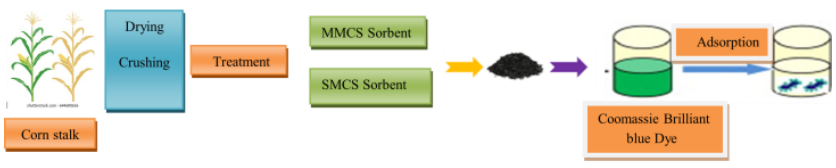

Abstract

In the present work, corn stalk was used as a low cost adsorbent for removal of anionic dye (Coomassie Brilliant blue "CBB"). Corn stalk was treated with two methods to inform Modified corn stalk with magnetic particles (MMCS) and Acid hydrolysis of corn stalk using sulfuric acid (SMCS). Comparison between raw and treated corn stalk in dye removal was done. The effect of various parameters as dye concentration (5 to $25 \mathrm{mg} / \mathrm{L})$, particle size $(4 \mathrm{~mm}-125 \mu \mathrm{m})$, adsorbent dose (1 to $10 \mathrm{~g} / \mathrm{L}$ ), shaking rate (100 to $250 \mathrm{rpm}$ ), Temperature $\left(15\right.$ to $\left.45^{\circ} \mathrm{C}\right)$ and $\mathrm{pH}(3$ to 11$)$ were investigated versus time interval. The results summarize that the highest \% removal of dye was $85 \%$ by using raw corn stalk followed by SMCS about $80 \%$ and $50 \%$ for MMCS. Different kinetic models were applied; the results suggested that adsorption of CBB dye for raw and treated corn stalk follows the pseudo second order model.

Keywords: Coomassie Brilliant blue, anionic dye, kinetic, adsorption, corn stalk.

\section{Introduction}

Water is essential for the survival of all living organisms. Today contamination of freshwater systems with a large variety of pollutants could be a subject of great concern. Out of all the contaminants present in industrial effluents, dyes are a very important class of pollutants and might be identified by even human eye. Dyes are used as coloring agents in an exceedingly type of industries like textiles, food, paper, rubber, plastics, cosmetics, leather, etc.

The discharge of wastewater from these industries to resources of water causes unavoidable problems because of the toxic and unsightly nature of dyes. The presence of dyes in water in trace amount is undesirable because it has negative effect on environmental and human health due to most of them are toxic, mutagenic and carcinogenic (Soni et al., 2012), and cause severe damage to the central system, systema digestorium and liver of human bodies (Tanga et al., 2019), even at low concentrations. Several techniques like flocculation, adsorption, oxidation, electrolysis, biodegradation, ion-exchange, photo catalysis are employed for the removal of dyes from wastewater. Amongst the varied techniques, adsorption has received considerable attention because of its several advantages in terms of cost, easy operation, flexibility and ease of design and insensitivity to toxic pollutants (Crini, 2005; Rafatullah et al., 2010).

Adsorption can be defined as an important surface phenomenon usually describes the attachment of particles (ions, atoms, and molecules) either from the gas phase or from the solution on the surface of a solid material.

A good adsorbent should possess large surface area containing many active sites. Figure 1 shows the mechanism of adsorption as it occurs in three steps (Kannan and Sundaram, 2001).

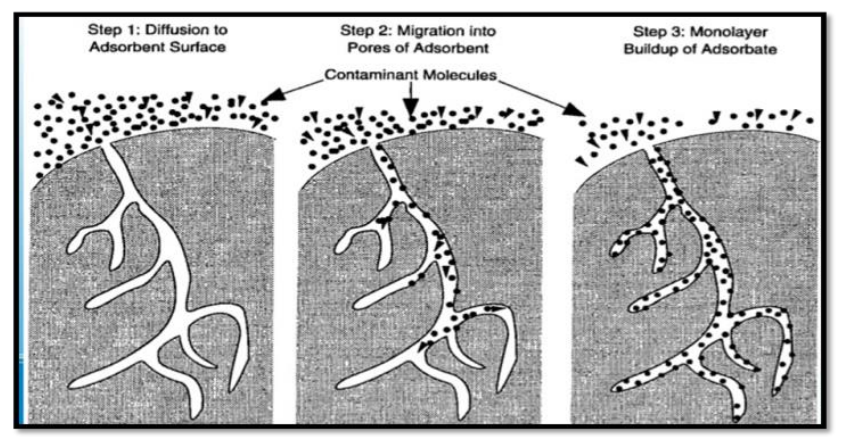

Figure 1. Adsorption mechanism (Kannan and Sundaram2001)

Adsorption process can be classified as physical or chemical adsorption. They are different in: Adsorption of Molecules, Selective process, Formation of layers of adsorbate 
molecules, Adsorption rate relation with increasing temperature (Lee et al., 2006).

Agricultural and industrial sectors dispose of large amounts of untreated waste, which may pollute the land, water and air, as a result damage the ecosystem. Within the last few years many ideas have been introduced in order to properly dispose of these wastes, such as intensive use as adsorbents. Pollutant removal especially for dye removal where it showed high adsorption capacity.

Agriculture waste is principally composed of three structural components: lignin, cellulose and hemicellulose. The three components have different structures and polarities, in order that they yield different ends up in the method of chemical reactions. The solidity of the three compounds is additionally different when the biomass is treated with acid or alkali solution. As an example, the treatment of biomass with $\mathrm{NaOH}$ or $\mathrm{KOH}$ can effectively dissolve lignin and hemicellulose; as a result, it may be expected that certain pores are formed when some components are dissolved. Many low cost adsorbents like jack fruit peel (Hameed, 2009a), garlic peel (Hameed, Ahmad, 2009), zeolite (Hor et al., 2016), pine apple stem (Hameed et al., 2009), corn cobs (Reddy et al., 2016), longan shell (Wang et al., 2016), hazelnut shell (Dogan et al., 2009), spent tea leaves (Hameed, 2009b), are reported in literature for the adsorption of dyes. As the plant biomass may be a natural renewable source that may be converted into useful material and energy (Klass, 1998). Corn stalks are agricultural by-products and are currently of no value. Disposal of residue from agriculture is currently a serious economic and ecological issue. However, the abundance and availability of corn stalk as agricultural byproduct make them good sources of raw materials for lots of uses, and converting it to adsorbents like carbon represents a possible outlet. Egypt annually produces 3.12 million a lot of corn stalk by-product. Recently, there are several reports on the economic removal of dye.

Bio adsorbents such as rice husk (Ramakrishna and Viraraghavan, 1997), waste coir pith (Klass, 1998) mahogany sawdust, rice husk (Scurlock et al., 2000) orange peel (Shin et al., 1989), bagasse pith (Faust and Aly, 1983), barley husk (Weber Jr, 1972), and banana pith (Ghosh and Bhattacharyya, 2002), banana peels (Munagapati et al., 2018) etc., which have been found to be highly effective, cheap and eco-friendly. New economical, easily available and highly effective adsorbents are still needed. Conversion of corn stalk to a value-added product such as adsorbent will help to solve part of the problem of waste management in Egypt (Husseien et al., 2009).

Aim of this work was Studying the possibility of using corn stalks as adsorbent materials for removal of anionic dyes. Also modification of corn stalks adsorbent by nano magnetic particles and, acid hydrolysis using sulfuric acid was done and study the effect of this on the adsorption process. The influence of different parameters, for example contact time, $\mathrm{pH}$ solution, adsorbent dosage, initial dye concentration and temperature, was evaluated in a batch experiment. The kinetic study was fitted by different models, namely pseudo-first-order, pseudo-second order.

\section{Materials and methods}

\subsection{Adsorbate material}

Coomassie Brilliant blue dye (CBB) is an anionic dye (Acidic) with $\lambda_{\max }=550 \mathrm{~nm}$, color index $=42660$, chemical formula $=\mathrm{C}_{45} \mathrm{H}_{44} \mathrm{~N}_{3} \mathrm{NaO}_{7} \mathrm{~S}_{2}$ and $\mathrm{M} . \mathrm{W}=825.97 \mathrm{~g} / \mathrm{mol}$, as in Figure 2 (Sadia et al., 2012).

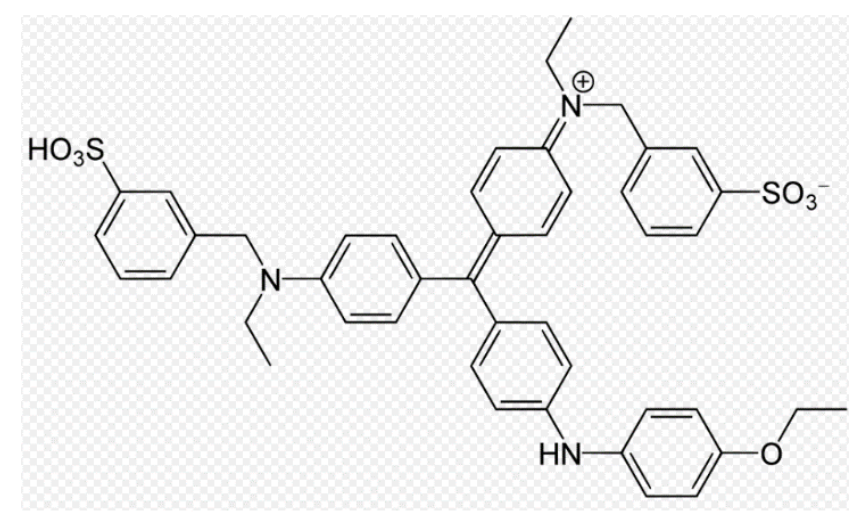

Figure 2. Coomassie Brilliant blue chemical structure

(Sadia et al., 2012)

The stock solution was prepared by dissolving $1 \mathrm{~g}$ of dye in $1000 \mathrm{ml}$ of distilled water, the experimental solutions was prepared by diluting the stock solution.

\subsection{Adsobent material (corn stalk)}

Corn stalk is the selected adsorbent used in this work, it was collected from farms at harvest time and be stripped to remove outer layers then wash to remove any undesirable matters, cut and dried in sunlight then in oven at $80{ }^{\circ} \mathrm{C}$ to remove any humidity. Crush the dried cut corn stalk and sieved to get different particle sizes range from $125 \mu \mathrm{m}$ to $4 \mathrm{~mm}$.

\subsection{Experimental methods and measurements}

\subsubsection{Modification of corn stalk with magnetic particles}

2.1g of $\mathrm{FeSO}_{4} .7 \mathrm{H}_{2} \mathrm{O}$ and 3.1g of $\mathrm{FeCl}_{3} .6 \mathrm{H}_{2} \mathrm{O}$ were dissolved in $80 \mathrm{ml}$ of distilled water, the solution was heated to $80^{\circ} \mathrm{C}$ with vigorous stirring. Then add $10 \mathrm{~mL}$ of ammonia with concentration of $25 \%$ for complete growth of nano particle crystals. $10 \mathrm{~g}$ of $250 \mu \mathrm{m}$ corn stalk was added to previous solution with continuous stirring at $80^{\circ} \mathrm{C}$ for $30 \mathrm{~min}$. let the solution to be cooled and settled then washed with distilled water (Garg et al., 2003).

\subsubsection{Modification of corn stalk using acid hydrolysis}

Mixing 1:2 (w/w) corn stalk $(250 \mu \mathrm{m})$ to sulfuric acid $(98 \%)$, stirring manually then left it for $24 \mathrm{hr}$, after that add sufficient amount of distilled water, shake well and then filtrate, this process was repeated until $\mathrm{pH}$ reaches 6 , then dried the dehydrated corn stalk for $24 \mathrm{hr}$ at $80{ }^{\circ} \mathrm{C}$ (Dursun et al., 2007).

\subsection{Batch adsorption}

$0.1 \mathrm{~g}$ of adsorbent was added to $50 \mathrm{ml}$ of different dye concentration solutions; shake the solution at 200rpm for 3 hours at room temperature. The samples were withdrawn at different time intervals, then analyzed using UV/Vis (Ultrospec 2000 - Pharmacia Biotech) spectrophotometer at wave length of $550 \mathrm{~nm}$. 
The amount of adsorption was calculated using the following equation:

$$
q_{\mathrm{e}}=\left(C_{0}-C_{\mathrm{e}}\right) * V / W
$$

$C_{0}$ and $C_{\mathrm{e}}(\mathrm{mg} / \mathrm{L})$ are the initial and equilibrium concentrations of the $\mathrm{CBB}$ dye, respectively, $V(L)$, the volume of $\mathrm{CBB}$ dye solution, and $W(\mathrm{~g})$, the weight of dry sorbent used.

The removal efficiency was calculated according to the following equation:

$$
\% \operatorname{Re}=\left(C_{0}-C\right) / C_{0} * 100
$$

Where $C_{0}$ and $C(\mathrm{mg} / \mathrm{L})$ are the initial and concentration after adsorption at different time intervals (Abu-Saied and Nahla, 2020).

\section{Results and discussion}

\section{1. \% Removal of dye by raw corn stalk}

\subsubsection{Initial concentration}

Different CBB dye concentration from 5 to $25 \mathrm{mg} / \mathrm{L}$ was tested using raw corn stalk (RCS) as shown in Figure 3. By increasing the dye concentration the \% removal increase to reach $85 \%$ at $10 \mathrm{mg} / \mathrm{L}$ as the driving force of mass transfer increased which cause \% removal increase after that \% removal start to decrease to reach $43 \%$ at $25 \mathrm{mg} / \mathrm{L}$, this behavior may be due to the saturation of adsorption sites on the adsorbent surface. While by increasing time there is a slight increase at the total time interval as the highest value of $\%$ removal was at the first $60 \mathrm{~min}$.

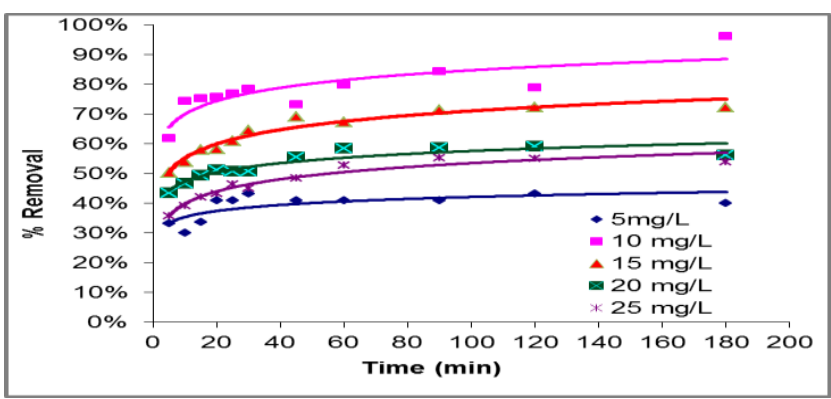

Figure 3. Effect of initial CBB dye concentration on \% removal at 25 C, 200rpm. $250 \mu \mathrm{m}$ particle size, $2 \mathrm{~g} / \mathrm{L} \mathrm{RCS}$

\subsubsection{Particle size}

Figure 4, showed the effect of using different RCS particle size ranging from $(4 \mathrm{~mm}-125 \mu \mathrm{m})$. By decreasing the particle size the \% removal increased, this may be due to increase of surface area which provided more active sites for adsorption process to take place to reach maximum value at $250 \mu \mathrm{m}$ with value of $72 \%$. With further decrease in particle size, $125 \mu \mathrm{m}$ the $\%$ removal decreased. This can be refers to that fine particle convert the adsorbent to emulsion in solution which decrease the active sites available for dye adsorption. Increasing experimental time than $60 \mathrm{~min}$ has useless effect.

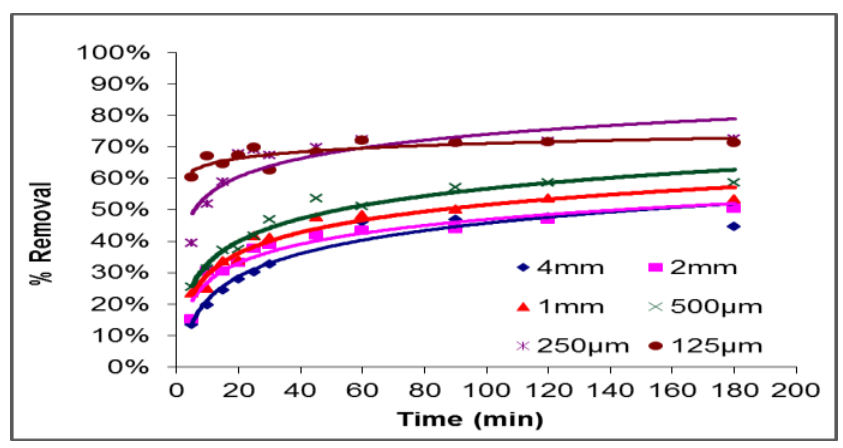

Figure 4. Effect of particle size on $\%$ removal of $C B B$ dye at $25^{\circ} \mathrm{C}$, $200 \mathrm{rpm}, \mathrm{CBB}$ concentration of $10 \mathrm{mg} / \mathrm{L}, 2 \mathrm{~g} / \mathrm{L} \mathrm{RCS}$

\subsubsection{Adsorbent dose}

Different adsorbent dose of RCS are studied as shown in Figure 5. The dose range from 1 to $10 \mathrm{~g} / \mathrm{L}$, by increasing the adsorbent dose the \% removal increased to reach maximum value at $4 \mathrm{~g} / \mathrm{L}$ after that the $\%$ removal started to decrease. This behavior can be shown at lower adsorbent dose the adsorbate is more easily accessible while by increasing the dose more than $4 \mathrm{~g} / \mathrm{L}$ the \% removal decrease due to accumulation of adsorbent particles which decreasing the active sites for dye removal. The best time interval for highest \% removal for different adsorbent doses was $60 \mathrm{~min}$.

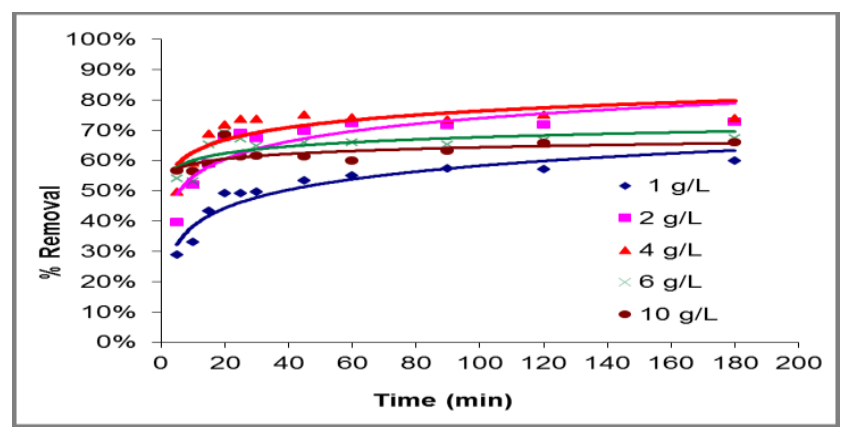

Figure 5. Effect of RCS dose on \% removal of CBB dye at $25^{\circ} \mathrm{C}$, $200 \mathrm{rpm}, \mathrm{CBB}$ concentration of $10 \mathrm{mg} / \mathrm{L}$, particle size of $250 \mu \mathrm{m}$

\subsubsection{Shaking rate}

Figure 6 illustrated the change in stirring speed from 100 to $250 \mathrm{rpm}$ comparing with static mode. By increasing the shaking rate the $\%$ removal increased to reach maximum value $68 \%$ at $200 \mathrm{rpm}$ after only $30 \mathrm{~min}$ then started to decrease to minimum value at $250 \mathrm{rpm}$. The increase of rpm cause decreasing of boundary layer resistance of the transfer adsorbate molecules from the bulk solution to the adsorbent surface, so the diffusion increased with increasing rpm.

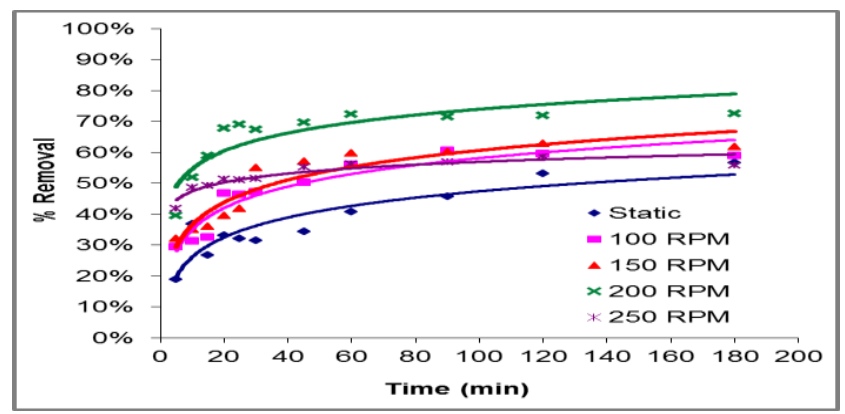

Figure 6. Effect of shaking rate on $\%$ removal of $\mathrm{CBB}$ dye at $25^{\circ} \mathrm{C}$, CBB concentration of $10 \mathrm{mg} / \mathrm{L}, 2 \mathrm{~g} / \mathrm{L} \mathrm{RCS}$, particle size of $250 \mu \mathrm{m}$ 


\subsubsection{Temperature}

Figure 7 showed the effect of changing temperature from 15 to $45^{\circ} \mathrm{C}$. It is obvious that the $\%$ dye removal increased from $37 \%$ to $70 \%$ at $25^{\circ} \mathrm{C}$ after $60 \mathrm{~min}$. The decrease of adsorption capacity with increasing temperature than 25 ${ }^{\circ} \mathrm{C}$ indicated that the adsorption was an exothermic process. Increasing temperature caused decrease in the adsorptive forces between the dye species and the active sites on the adsorbent surface resulting of decreasing adsorption capacity.

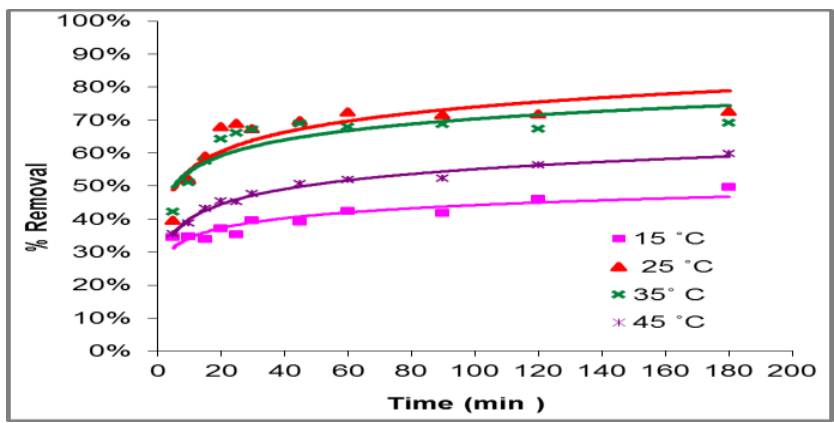

Figure 7. Effect of temperature on \% removal of CBB dye at $2 \mathrm{~g} / \mathrm{L}$ $\mathrm{RCS}, \mathrm{CBB}$ concentration of $10 \mathrm{mg} / \mathrm{L}$, particle size of $250 \mu \mathrm{m}$, 200rpm

\subsection{6. $\mathrm{pH}$}

The effect of changing $\mathrm{pH}$ from 3 to 11 is shown in Figure 8. The figure showed that by increasing the $\mathrm{pH}$ value the $\%$ removal decreased, as at $\mathrm{pH}=3$ the $\%$ removal was $83 \%$ after 30 min while it was $50 \%$ for $\mathrm{pH}=11$. At low $\mathrm{pH}$, the positive charge on the solution interface will increase and the adsorbent surface appears positive charged, which results in an increase in anionic dye adsorption (Ahmad et al., 2020).

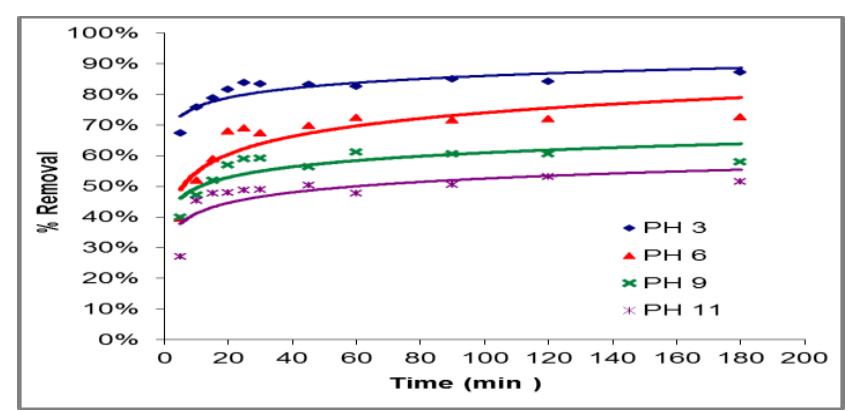

Figure 8. Effect of $\mathrm{pH}$ on $\%$ removal of $\mathrm{CBB}$ dye at $25^{\circ} \mathrm{C}, \mathrm{CBB}$ concentration of $10 \mathrm{mg} / \mathrm{L}, 2 \mathrm{~g} / \mathrm{L} \mathrm{RCS}$, particle size of $250 \mu \mathrm{m}$, 200rpm

\section{2. \% Removal of dye by modified corn stalk}

\subsubsection{Adsorbent dose}

Figure 9 illustrated the relation between \% removal and time for different adsorbent dose from 1 to $6 \mathrm{~g} / \mathrm{L}$ using corn stalk modified by magnetic particles. The figure showed the same behavior for RCS as by increasing the adsorbent dose the \% removal increased and the maximum value was for $4 \mathrm{~g} / \mathrm{L}$ equal $53 \%$ after $20 \mathrm{~min}$.

While Figure 10 showed the effect of changing dose of acid hydrolyses corn stalk using sulfuric acid" SMCS" on \% removal of $\mathrm{CBB}$ from the solution. It is cleared that when dose increased from $1 \mathrm{~g} / \mathrm{L}$ to $2 \mathrm{~g} / \mathrm{L}$ as the $\%$ removal increased from $37 \%$ to $67 \%$ after $30 \mathrm{~min}$. after that (at 4 $10 \mathrm{~g} / \mathrm{L}$ ) the increasing of dose has insignificant behavior.

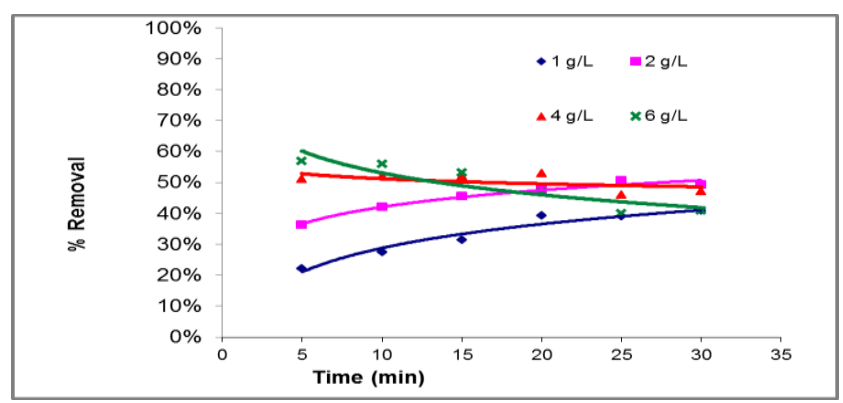

Figure 9. Effect of MMCS dose on \% removal of $\mathrm{CCB}$ dye at $25^{\circ} \mathrm{C}$, CBB concentration of $10 \mathrm{mg} / \mathrm{L}$, particle size of $250 \mu \mathrm{m}, 200 \mathrm{rpm}$

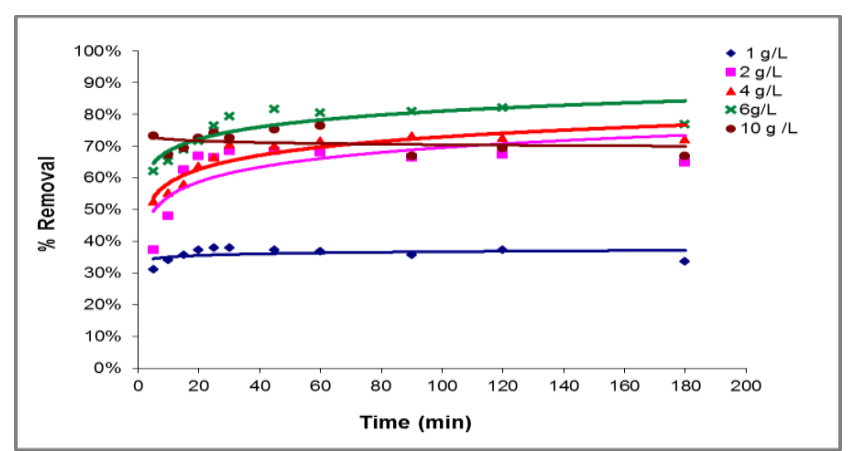

Figure 10. Effect of SMCS dose on \%Removal of CBB dye at temperature $25^{\circ} \mathrm{C}, \mathrm{CBB}$ concentration of $10 \mathrm{mg} / \mathrm{L}$, particle size of $250 \mu \mathrm{m}, 200 \mathrm{rpm}$

\subsubsection{Agitation rate}

Effect of agitation rate was studied in Figure 11 . By changing the static to dynamic mode, changing the rpm from 100 to $200 \mathrm{rpm}$ the $\%$ removal increased to reach the maximum value at $200 \mathrm{rpm}$ to reach $50 \%$ after $30 \mathrm{~min}$.

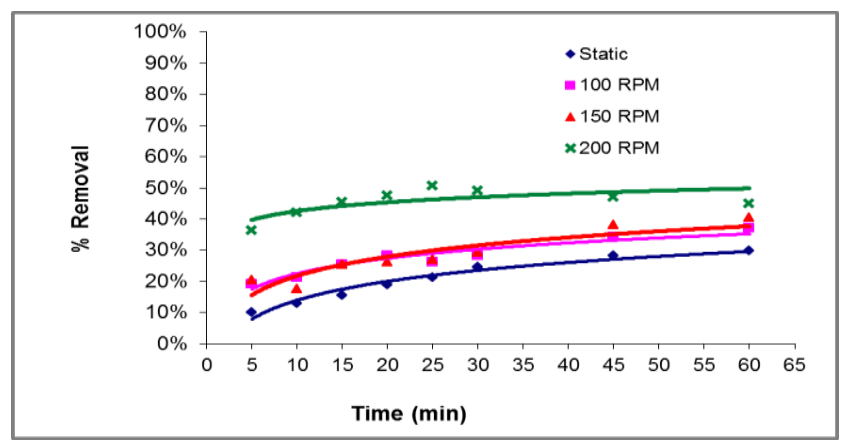

Figure 11. Effect of agitation rate on \% removal of CCB dye at $25^{\circ} \mathrm{C}, \mathrm{CBB}$ concentration of $10 \mathrm{mg} / \mathrm{L}, 2 \mathrm{~g} / \mathrm{L} \mathrm{MMCS}$, particle size of $250 \mu \mathrm{m}$

Figure 12 showed the similar trend for RCS and MMCS in the effect of shaking rate on \% removal of CBB to reach the maximum value at $200 \mathrm{rpm}$ after $30 \mathrm{~min}$ which equal $67 \%$.

\subsubsection{Temperature}

Figure 13 illustrated the relation between changing temperature from 15 to $45^{\circ} \mathrm{C}$ and \% removal. By increasing temperature the \% removal reach the maximum value at $25^{\circ} \mathrm{C}=50 \%$ after $30 \mathrm{~min}$. and started to decrease by increasing temperature to $45^{\circ} \mathrm{C}$ for the same reason illustrated for RCS. 


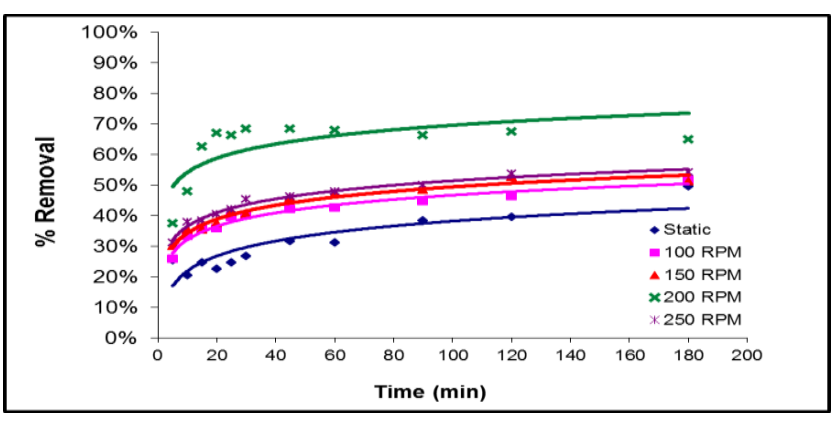

Figure 12. Effect of agitation rate on \%Removal of $C B B$ dye at temperature $25^{\circ} \mathrm{C}, \mathrm{CBB}$ concentration of $10 \mathrm{mg} / \mathrm{L}$, SMCS dose $2 \mathrm{~g} / \mathrm{L}$, particle size of $250 \mu \mathrm{m}$

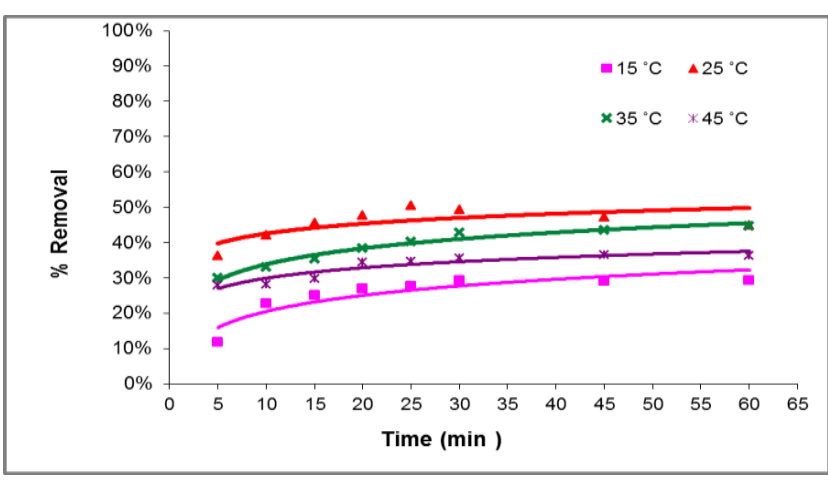

Figure 13. Effect of Temperature on \% removal of CCB dye at $25^{\circ} \mathrm{C}, \mathrm{CBB}$ concentration of $10 \mathrm{mg} / \mathrm{L}, 2 \mathrm{~g} / \mathrm{L} \mathrm{MMCS}$, particle size of $250 \mu \mathrm{m}, 200 \mathrm{rpm}$

While Figure 14 showed the same trend of relationship between temperature and \% removal of CBB in case of RCS and MMCS as the process is exothermic, it is obvious that the \% removal increased from $10 \%$ to $67 \%$ from $15^{\circ} \mathrm{C}$ to $25^{\circ} \mathrm{C}$ then decreased again to reach $27 \%$ at $45^{\circ} \mathrm{C}$.

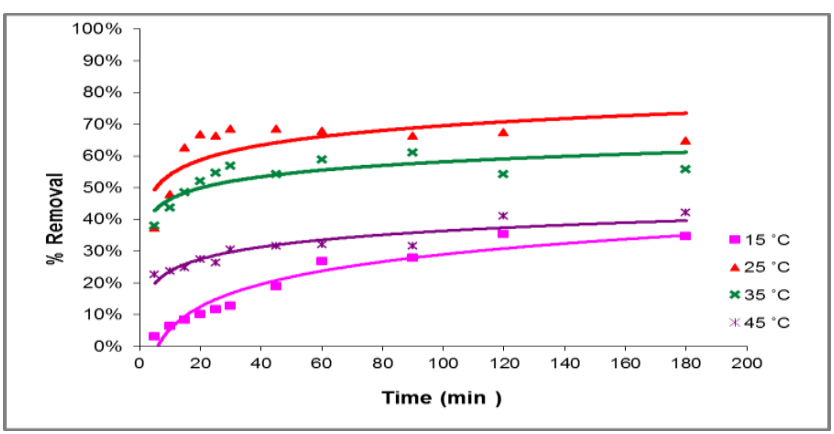

Figure 14. Effect of Temperature on \%Removal of CBB dye, CBB concentration of $10 \mathrm{mg} / \mathrm{L}$, SMCS dose $2 \mathrm{~g} / \mathrm{L}$, particle size of $250 \mu \mathrm{m}, 200 \mathrm{rpm}$

\subsection{4. $p H$}

By increasing $\mathrm{pH}$ value from 3 to 11 as shown in Figure 15, the $\%$ removal of dye increased to reach $79 \%$ at $\mathrm{pH}=3$ after $30 \mathrm{~min}$, the result concludes that the MMCS give high adsorption results in acidic medium than alkaline.

Figure 16 illustrated also the same behavior for RCS and MMCS for the effect of $\mathrm{pH}$ on the \% removal, as the maximum value was for $\mathrm{pH}=3$ which equal about $80 \%$ after $20 \mathrm{~min}$. and decreased to $23 \%$ at $\mathrm{pH}=11$.

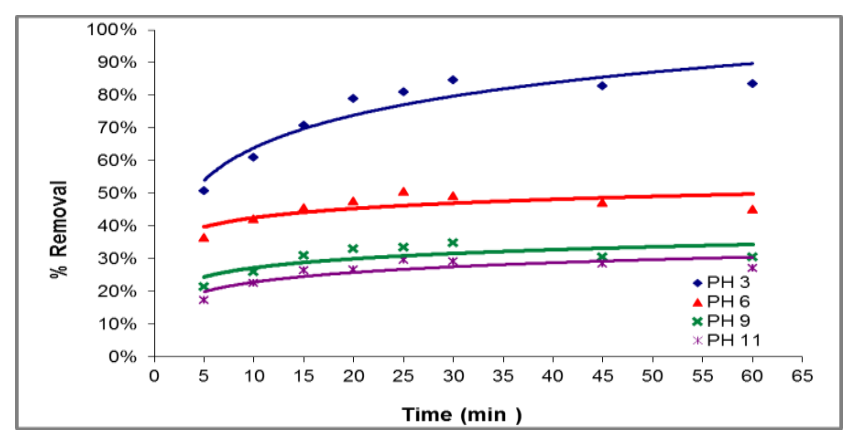

Figure 15. Effect of $\mathrm{pH}$ on \% removal of $\mathrm{CCB}$ dye at $25^{\circ} \mathrm{C}, \mathrm{CBB}$ concentration of $10 \mathrm{mg} / \mathrm{L}, 2 \mathrm{~g} / \mathrm{L} \mathrm{MMCS}$, particle size of $250 \mu \mathrm{m}$, 200rpm

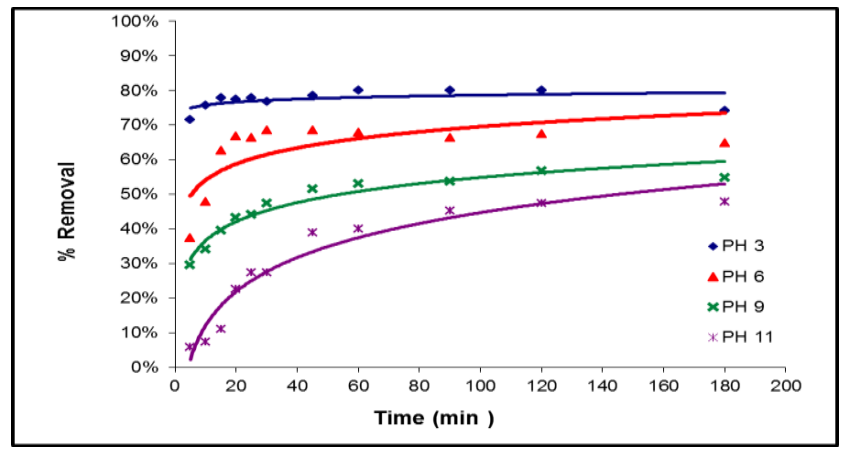

Figure 16. Effect of $\mathrm{pH}$ on \% Removal of $\mathrm{CBB}$ dye at temperature $25^{\circ} \mathrm{C}, \mathrm{CBB}$ concentration of $10 \mathrm{mg} / \mathrm{L}$, SMCS dose $2 \mathrm{~g} / \mathrm{L}$, particle size of $250 \mu \mathrm{m}, 200 \mathrm{rpm}$

\section{Adsorption kinetics study}

In order to investigate the adsorption kinetics of dye adsorption on adsorbent, different models are applied which represented with the following equations: (Sara and Tushar, 2012)

1. The first-order kinetic model:

$$
\log C=\log C_{0}-\frac{K}{2.303} \times t
$$

2. The pseudo-first-order kinetic model:

$$
\log \left(q_{\mathrm{e}}-q_{\mathrm{t}}\right)=\log q_{\mathrm{e}}-\frac{k_{1}}{2.303} t
$$

3. The pseudo-second-order kinetic model:

$$
\frac{t}{q_{\mathrm{t}}}=\frac{1}{k_{2} q_{\mathrm{e}}^{2}}+\frac{1}{q_{\mathrm{e}}} t
$$

Where the equilibrium rate constant is $k_{1}(1 / \mathrm{min})$, and second order constants is $k_{2}(\mathrm{~g} / \mathrm{mg} \mathrm{min}) q_{\mathrm{e}}$ is the amount of dye adsorbed on the surface at equilibrium $(\mathrm{mg} / \mathrm{g}), q_{t}$ is the amount of dye adsorbed at different times $(\mathrm{mg} / \mathrm{g})$.

By applying the first order, pseudo first and second order kinetic models on raw corn stalk at the different concentrations as shown in Figures 17 to 19 and Table 1, it is obvious that the correlation coefficients of pseudo second order were found the highest value and also the theoretical values were very similar to experimental values, this results suggested that adsorption of CBB dye for RCS follows the pseudo second order model. 


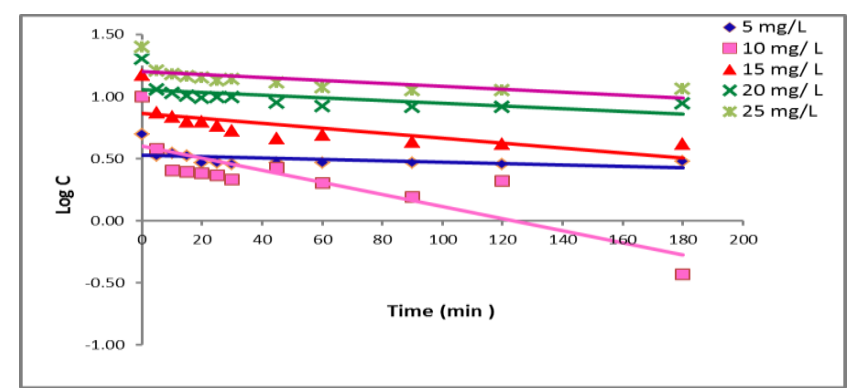

Figure 17. The first order kinetic model for adsorption of $\mathrm{CBB}$ dyes using RCS adsorbent at different initial CBB concentrations, $2 \mathrm{~g} / \mathrm{L}, 250 \mu \mathrm{mm} \mathrm{pH}=, 200 \mathrm{rpm}$ at $25^{\circ} \mathrm{C}$

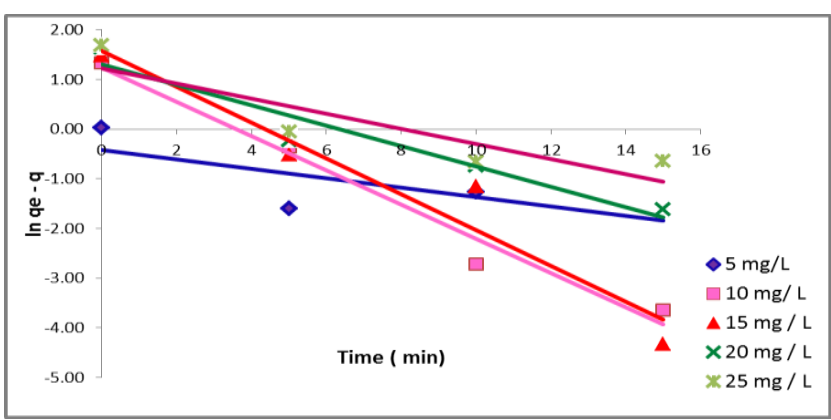

Figure 18. The pseudo first order kinetic model for adsorption of CBB dyes using RCS adsorbent at different initial CBB concentrations, $2 \mathrm{~g} / \mathrm{L}, 250 \mu \mathrm{mm} \mathrm{pH}=, 200 \mathrm{rpm}$ at $25^{\circ} \mathrm{C}$

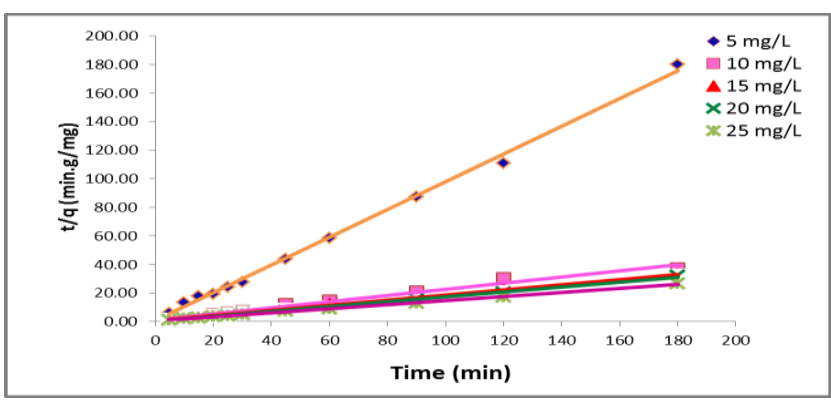

Figure 19. The pseudo second order kinetic model for adsorption of CBB dyes using RCS adsorbent at different initial CBB concentrations, $2 \mathrm{~g} / \mathrm{L}, 250 \mu \mathrm{mm} \mathrm{pH}=200 \mathrm{rpm}$ at $25^{\circ} \mathrm{C}$

\section{Kinetic model comparison for different types of adsorbent used}

Figure 20-22 and Table 2 represent the pseudo second order kinetic model for adsorption of CBB using raw

Table 1 Kinetic parameters and the correlation coefficients at different initial CBB concentrations on RCS

\begin{tabular}{|c|c|c|c|c|c|c|c|c|c|c|c|}
\hline \multirow{2}{*}{$C_{0} \mathrm{mg} / \mathrm{L}$} & \multirow{2}{*}{$\begin{array}{l}q_{\text {e(exp) }} \\
\mathrm{mg} / \mathrm{g}\end{array}$} & \multicolumn{3}{|c|}{ First order kinetics } & \multicolumn{3}{|c|}{ Pseudo First order kinetics } & \multicolumn{4}{|c|}{ Pseudo second order kinetics } \\
\hline & & $R^{2}$ & $C_{0} \mathrm{mg} / \mathrm{L}$ & $\mathrm{K} \mathrm{min}^{-1}$ & $R^{2}$ & $q_{\mathrm{e}} \mathrm{mg} / \mathrm{g}$ & $\mathrm{K}_{1} \mathrm{~min}^{-1}$ & $q_{\text {e(exp) }} \mathrm{mg} / \mathrm{g}$ & $R^{2}$ & $q_{\mathrm{e}} \mathrm{mg} / \mathrm{g}$ & $\mathrm{K}_{2} \mathrm{~min}^{-1}$ \\
\hline 5 & 1.026 & 0.200 & 3.380 & 0.0004 & 0.604 & 1.511 & 0.095 & 1.026 & 0.997 & 1.031 & 1.383 \\
\hline 10 & 3.789 & 0.679 & 3.963 & 0.0092 & 0.975 & 3.466 & 0.345 & 3.789 & 0.984 & 4.651 & 0.0342 \\
\hline 15 & 4.368 & 0.482 & 3.034 & 0.0046 & 0.935 & 4.821 & 0.360 & 4.368 & 0.999 & 5.587 & 0.0420 \\
\hline 20 & 5.132 & 0.317 & 2.075 & 0.0023 & 0.930 & 3.669 & 0.205 & 5.132 & 0.998 & 5.814 & 0.0833 \\
\hline 25 & 5.421 & 0.453 & 2.838 & 0.0023 & 0.784 & 3.397 & 0.152 & 5.421 & 0.998 & 7.042 & 0.0299 \\
\hline
\end{tabular}

Table 2 Kinetic parameters and the correlation coefficient of pseudo-second -order kinetic model for adsorption of CBB dyes using RCS, MMCS and SMCS at optimum conditions

\begin{tabular}{|c|c|c|c|c|c|}
\hline \multirow{2}{*}{ Adsorbent type } & \multirow{2}{*}{$q_{\text {e(exp) }} \mathrm{mg} / \mathrm{g}$} & \multicolumn{4}{|c|}{ Pseudo second order kinetics } \\
\hline & & $R^{2}$ & $q_{\mathrm{e}} \mathrm{mg} / \mathrm{g}$ & $\mathrm{K}_{2} \mathrm{~min}^{-1}$ & h \\
\hline RCS & 3.395 & 0.999 & 3.704 & 0.0896 & 1.229 \\
\hline MMCS & 2.382 & 0.994 & 2.320 & -8.444 & -45.449 \\
\hline SMCS & 4.171 & 0.999 & 4.149 & 3.227 & 55.550 \\
\hline
\end{tabular}

and modified corn stalk. The figure showed that the higher value of $R_{2}$ was for RCS and MMCS followed by SMCS.

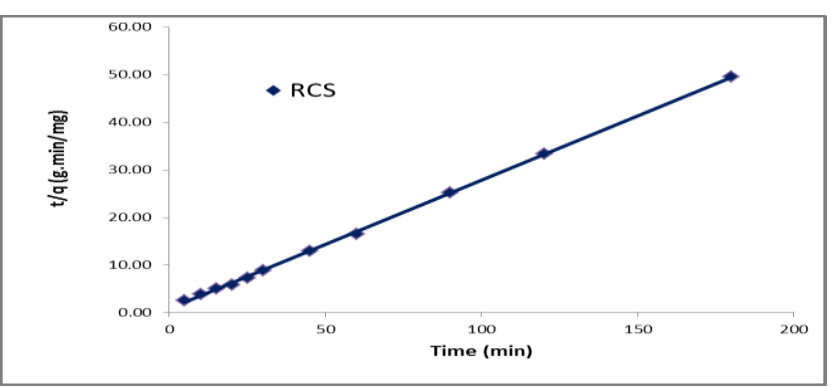

Figure 20. The pseudo second order kinetic model for adsorption of CBB dye using RCS adsorbent, $2 \mathrm{~g} / \mathrm{L}, 250 \mu \mathrm{m}, 200 \mathrm{rpm}, \mathrm{pH}=6$ at $25^{\circ} \mathrm{C}$

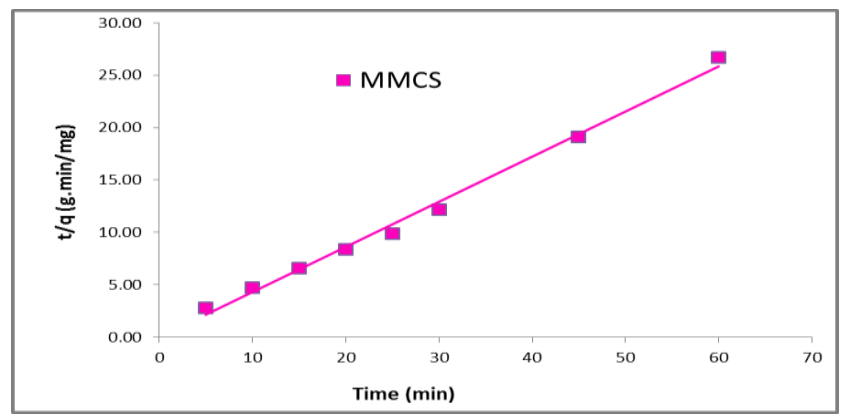

Figure 21. The pseudo second order kinetic model for adsorption of CBB dye using MMCS adsorbent, $2 \mathrm{~g} / \mathrm{L}, 250 \mu \mathrm{m}, 200 \mathrm{rpm}, \mathrm{pH}=6$ at $25^{\circ} \mathrm{C}$

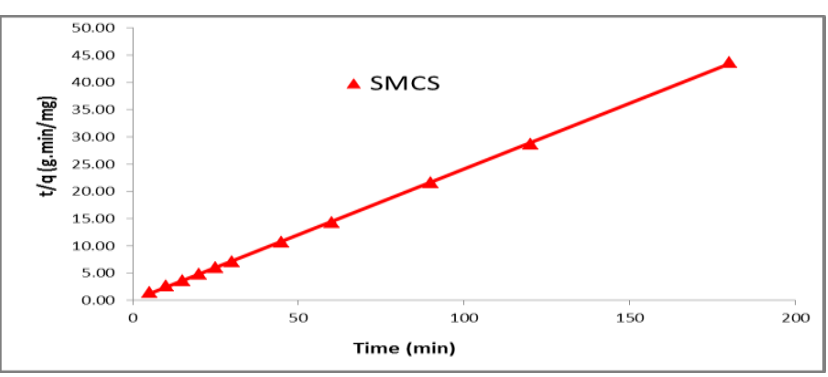

Figure 22. The pseudo second order kinetic model for adsorption of CBB dye using SMCS adsorbent, 2g/L, 250 $\mu \mathrm{m}, 200 \mathrm{rpm}, \mathrm{pH}=6$ at $25^{\circ} \mathrm{C}$ 


\section{Conclusions}

Corn stalk as a one of agriculture waste was tested comparing with rapid and simple modified adsorbent by using two modification methods. The uptake of anionic dye was increased with decrease in initial concentration of dye and particle size of adsorbents and also increased with increase in adsorbent dose used, shaking rate and contact time. The optimum conditions recommended for highest \% removal of dye $=85 \%$ was $10 \mathrm{mg} / \mathrm{L}$ initial concentration, $2 \mathrm{~g} / \mathrm{L}$ sorbent with $250 \mu \mathrm{m}, 150-200 \mathrm{rpm}$ shaking rate at room temperature and acidic solution with $\mathrm{pH}=3$ at $25^{\circ} \mathrm{C}$. By comparing the resulting data across studying different variables of raw and modified corn stalk, the modification did not enhance the adsorbent behavior with valuable amount than raw corn stalk as expected. But modified corn stalk using magnetic particles (MMCS) can be valuable as the adsorbent can be easily collected and reused using a magnet The kinetic adsorption was represented by pseudosecond order model at the optimum conditions for all types of adsorbent used as a best fit model with $R^{2}=0.99$. Finally the results indicated that corn stalk could be employed as low cost alternative to commercial activated carbon for anionic dye removal from wastewater.

\section{References}

Abu-Saied M.A. and Nahla Taha A. (2020), Purification of waste water from cationic dye using SPGMA polymer: Isotherm and Kinetic study, Global Nest Journal, 22(2), 179-184.

Alhujaily A., Yu H., Zhang X. and Ma F. (2020), Adsorptive removal of anionic dyes from aqueous solutions using spent mushroom waste, Applied Water Science, 10, 183.

Crini G. (2005), Non-conventional low-cost adsorbents for dye removal: a review. Bioresource Technology, 97, 1061-1085.

Dawood S. and KantiSen T. (2012), Removal of anionic dye Congo red from aqueous solution by raw pine and acid-treated pine cone powder as adsorbent: Equilibrium, thermodynamic, kinetics, mechanism and process design. Water Research, 46(6), 1933-1946.

Dogan M., Abak H. and Alkan M. (2009), Adsorption of methylene blue onto Hazel- nut shell: Kinetics, mechanism and activation parameters. Journal of Hazardous Materials, 164, 172-181.

Dursun A., Gulbeyi D. and Ahmet A. (2007), Methylene blue adsorption from aqueous solution by dehydrated peanut hull. Journal of Hazardous Materials, 144, 171-179.

Faust D.S. and Aly M.O. (1983), Chemistry of Wastewater Treatment. Butter worth, Boston.

Garg V.K., Gupta R., Yadav A.B. and Kumar R.. (2003), Dye removal from aqueous solution by adsorption on treated sawdust. Bioresource Technology, 89, 121-124.

Ghosh D. and Bhattacharyya K.G. (2002), Adsorption of methylene blue on kaolinite. Applied Clay Science, 20, 295-300.

Hameed B.H. (2009a), Removal of cationic dye from aqueous solution using Jack fruit peel as non-conventional low cost adsorbents. Journal of Hazardous Materials, 162, 344-350.

Hameed B.H. (2009b), Spent tea leaves: A new non-conventional and low-cost ad- sorbent for removal of basic dye from aqueous solutions. Journal of Hazardous Materials, 161, 753759.

Hameed B.H. and Ahmad A.A. (2009), Batch adsorption of methylene blue from aqueous solution by garlic peel, an agricultural waste biomass. Journal of Hazardous Materials, 164, 870-875.

Hameed B.H., Krishni R.R. and Sata S.A. (2009), A novel agricultural waste adsorbent for the removal of cationic dye from aqueous solutions. Journal of Hazardous Materials, 162, 305-311.

Hor K.Y., Chee J.M.C., Chong M.N., Jin B., Saint C. and Poh P.E. (2016), Evaluation of physico chemical methods in enhancing the adsorption performance of natural zeolite as low-cost adsorbent of methylene blue dye from wastewater. Journal of Cleaner Production, 118, 197-209.

Husseien M., Amer A.A., El-Maghraby A. and Hamedallah N. (2009), A comprehensive characterization of corn stalk and study of carbonized corn stalk in dye and gas oil sorption. Journal of Analytical and Applied Pyrolysis, 86, 360-363.

Kannan N. and Sundaram M. (2001), Kineticks and mechanism of removal of methylene blue dye by adsorption on various carbons- acomparative study. Journal of Dyes and Pigments, 51, 25-40.

Klass D.L. (1998), Biomass for Renewable Energy Fuels and Chemicals. Academic press, San Diego, CA.

Lee J.W., Choi S.P., Thiruvenkatachari R., Shim W.G. and Moon H. (2006), Evaluation of the performance of Adsorption and coagulation processes for the maximum removal of reactive dyes. Journal of Dyes and Pigments, 69, 198-203.

Munagapati V.S., Yarramuthi V., Kim Y., Lee K.M. and Kim D.S. (2018), Removal of anionic dyes (Reactive Black 5 and Congo Red) from aqueous solutions using Banana Peel Powder as an adsorbent, Ecotoxicology and Environmental Safety, 148, 601-607.

Rafatullah M., Sulaiman O., Hashim R. and Ahmad A. (2010), Adsorption of methylene blue on low-cost adsorbents: A review. Journal of Hazardous Materials, 177, 70-80.

Ramakrishna K.R. and Viraraghavan T. (1997), Dye removal using low cost adsorbents. Water Science and Technology, 36(2-3), 189-196.

Reddy P.M.K., Verma P. and Subrahmanyam C. (2016), Biowaste derived adsorbent material for methylene blue adsorption. Journal of the Taiwan Institute of Chemical Engineers, 58, 500-508.

Sadia A., Muhammad I.D., Atta R.., Imran Q. and ljaz U.M. (2012), Thermodynamics and kinetic Sorption studies for the removal of comassie Brilliant Blue on Wheat Bran as a low cost adsorbent. Journal of Analytical Methods in Chemistry, 1-8.

Scurlock J.M.O., Dayton D.C. and Hames B. (2000), Bamboo: an overlooked biomass resource. Biomass Bioenergy, 19, 229244.

Shin F.G., Xian X.J., Zheng W.P. and Yipp M.W. (1989), Analysis of the mechanical properties and microstructure of bambooepoxy composites. Journal of Master Science, 24, 3483-3490.

Soni M., Sharma A.K., Srivastava J.K. and Yadav J.S. (2012) Adsorptive removal of Methylene blue dye from an aqueous solution using water hyacinth root powder as a low cost adsorbent. International Journal of Chemical Science and Applications, 3(3), 338-345.

Tanga Y., Zhaoa Y., Lina T., Lia Y., Zhoua R. and Pengc Y. (2019), Adsorption performance and mechanism of methylene blue by H3PO4- modified corn stalks. Journal of Environmental Chemical Engineering, 7, 103398. 
Wang Y., Zhu L., Jiang H., Hu F. and Shen X. (2016), Application of longan shell as non-conventional low-cost adsorbent for the removal of cationic dye from aqueous solution. Spectrochim Acta A, 159, 254-261.

Weber Jr. W.J. (1972), Phsico-Chemical Processes For Water Quality Control. Wiley Interscience, New York. 